Egyptian Journal of Aquatic Biology \& Fisheries

Zoology Department, Faculty of Science,

Ain Shams University, Cairo, Egypt.

ISSN 1110 - 6131 Vol. 22(2): 93- 101 (2018)

http://ejabf.journals.ekb.eg/

\title{
Checklist of phytoplankton species in the Egyptian Red Sea Coast of Hurghada
}

Sara G. Abbass; Fedekar F. Madkour and Mohamed A. Abu-El-Regal

Marine Science Department, Faculty of Science, Port Said University, Egypt

\section{ARTICLE INFO}

Article History:

Received: May 5, 2018

Accepted: June 4,2018

Available online:June 2018

Keywords:

Phytoplankton

Red Sea

Hurghada

Biodiversity

Egypt

\begin{abstract}
Surface phytoplankton samples were collected at twelve stations of Hurghada coast of the Red Sea. Phytoplankton samples were conducted monthly during the period from August 2014 to July 2015. The phytoplankton population was diversified accounting 138 species which comprised mainly of two groups; dinoflagellates (67 species) and diatoms (64 species), and the rest of species (7 species) belong to other four groups. The dominant genera, in terms of the number of species, were Tripos, Protoperidinium and Gonyaulax for dinoflagellates, while Chaetoceros, Rhizosolenia for diatoms. The present study added 35 new records to the proper Red Sea. Of these species, 17 species of diatoms and 15 dinoflagellates in addition to two species of coccolithophores and one species of Chlorophyceae.
\end{abstract}

\section{INTRODUCTION}

The Red Sea is a large marine ecosystem (2250 km long), lying between the African and the Asian continental shelves. It provides habitat for a wide range of marine species, some of which are endemic (Baars et al. 1998). Phytoplankton studies in the Red Sea started since 1900 through a few scattered different expeditions (Cleve 1900, 1903; Ostenfeld and Schmidt 1901; Schröder 1906; Karsten 1907; Matzenauer 1933). Halim (1969) reported the first review on the plankton of the oceanic water of the central Red Sea with collected data from the previous studies. He listed 125 dinoflagellates and 84 diatom species, and stated that genus Ceratium is the main component of phytoplankton in the Red Sea. Afterward, many studies on the phytoplankton species composition and standing crop of the northern Red Sea were conducted along either western coast (Egyptian) or eastern coast (Saudi Arabia) of the Red Sea and the two gulfs, Suez and Aqaba Gulfs.

Considering the studies in the western coast of the Red Sea and the two gulfs, Dowidar (1983) described 51 species belong to genus Ceratium in the Red Sea and Gulf of Suez. Ibrahim (1988) reported 111 species in the Foul bay. El-Shrif and Abo El-Ezz (2000) recorded a total of 106 phytoplankton species and varieties in the northern Red Sea and Gulf of Aqaba, including 23 species in Hurghada. Madkour (2000) and Madkour et al. (2007) constructed intensive study on the Suez Canal and northern end of Gulf of Suez, recording 287 species. Deyab et al. (2004) recorded 200 phytoplankton species in the Suez Canal, Suez Gulf and northwest Red Sea coast. In Halayib-Shalatin, Abel Rahman and Nassar (2005) found 25 species of phytoplankton associated with mangroves. 
Madkour et al. (2010) recorded 181 phytoplankton species in the southern of the Sinia Peninsula and the two Gulfs with dominance of dinoflagellates (116 species) than diatoms (60 species). Nassar et al. (2014) identified 145 phytoplankton species in the coastal water of the northwest Red Sea, while Nassar and Khairy (2014) gave a checklist of 207 phytoplankton species in the Egyptian Red Sea and some surrounding habitats during the period 1990-2010.

Phytoplankton community structure and species composition in the eastern coast of the Red Sea have been investigated through many studies (Shaikh et al. 1986; Khalil and Ibrahim 1988; Touliabah et al. 2010; Kürten et al. 2015; Devassy et al. 2016, 2017). Recently, Ismael (2015) reviewed the phytoplankton and primary productivity status in the Red Sea proper, Suez and Aqaba Gulfs since Halim (1969) and listed 389 species and varieties in the entire Red Sea. Devassy et al. (2017) added 118 species of phytoplankton species to the last review by Ismael (2015). All the previous studies in the western coast of the Red Sea were seasonal and covered large areas. Although, the phytoplankton community of the Red Sea has been studied since 1969s, the information about the phytoplankton species composition of the northern Red Sea of Egypt is scarce. The aim of the present research is to study the species composition of phytoplankton community with a check list of recorded species in the investigation area.

\section{MATERIALS AND METHODS}

\section{Study area}

The present study was carried out in the north western coast of the Red Sea off Hurghada, with an area of about $400 \mathrm{~km}^{2}$ extending about $40 \mathrm{~km}$ along coastline and $10 \mathrm{~km}$ seaward from coastline to the borders of Big Gifton Island. The area was divided into 12 stations as follow: four sites from north to south and at each site, three stations in perpendicular to coastline with $5 \mathrm{~km}$ distance between each station were taken (Fig. 1).

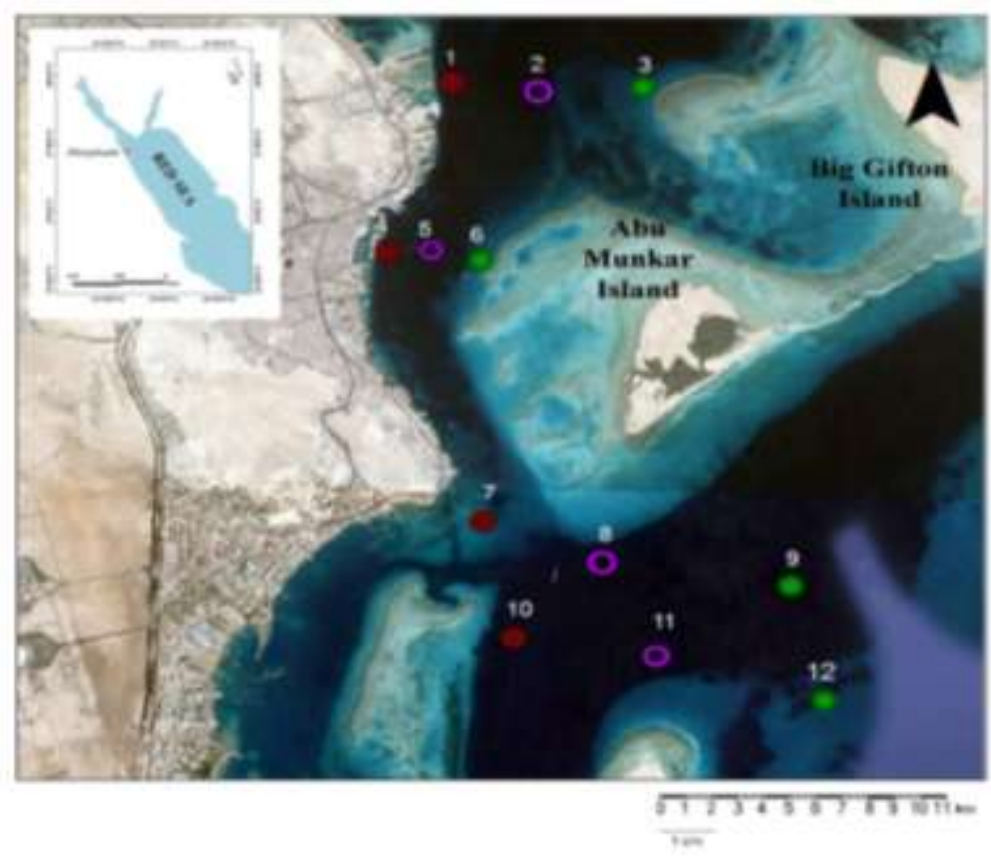

Fig. 1: Location of sampling sites. 


\section{Phytoplankton sampling and identification}

Phytoplankton samples were collected by net of $20 \mu \mathrm{m}$ mesh size $(20 \mathrm{~cm}$ mouth diameter and $60 \mathrm{~cm}$ length). The net was towed horizontally in the morning (7-9 a.m) for about $5 \mathrm{~min}$ at a speed of 1.5 knot. Samples were preserved immediately in $4 \%$ buffered formalin. Phytoplankton samples were collected monthly from August 2014 to July 2015 at all stations. Phytoplankton taxa were identified to the species level using many references; Cupp (1943); Hendey (1946); Stewart and Mattox (1975); Taylor (1976); Dodge 1982, 1985; Tomas (1997); Young et al. (2003); Al-Kandari et al. (2009). The valid and accepted names of the phytoplankton species were based on the taxonomic database sites such as AlgaeBase.com (AB), World Register of Marine Species (WoRMS), Nordic Microalgae and Aquatic Protozoa (NOD) and Integrated Taxonomic Information System (ITIS).

\section{RESULTS AND DISCUSSION}

A total of 138 species of phytoplankton belonging to 58 genera was recorded in the present study. The recorded species were classified into six divisions, of them, Bacillariophyceae (diatoms) and Dinophyceae (dinoflagellates) contained relatively close number of species (67 and 64, respectively), and collectively represented the main bulk (95\%) of the total phytoplankton community. Other divisions; Cyanophyceae (cyanobacteria), Haptophyta (coccolithophores), Ochrophyta (silicoflagellates) and Chlorophyceae (chlorophytes) were collectively represented by a very low number of species (7 species).

The last checklist and review on the phytoplankton species recorded in the Red Sea were performed by Nassar and Khairy (2014), Ismael (2015) and Devassy (2017). Nassar and Khairy (2014) in their review mentioned the presence of 128 species from the entire Egyptian Red Sea proper during 1990-2010 while Ismael (2015) reported 377 species and varieties in the proper Red Sea. The present study added 76 species to the review conducted by Nassar and Khairy (2014) while 67 species were added to that by Ismael (2015). In addition, 74 species was added to the species list by Devassy et al. (2017). When comparing the present study with Nassar and Khairy (2014), Ismael (2015) and Devassy et al. (2017), 35 species were found to be new to the water of the proper Red Sea (Table 1). Of these species, 17 species belong to diatoms (2 centric and 15 pennate diatoms), and 15 species from dinoflagellates, in addition to two species of coccolithophores (Emiliania huxleyi and Coronosphaera mediterranea) and one species of Chlorophyceae (Pterosperma undulatum).

In the present study, diatoms included 64 species belong to 35 genera with dominance of pennate diatoms (41 species) than centric $(23$ species $)$. The dominant genera, in terms of the number of species, were Chaetoceros (5 species) and Rhizosolenia (5 species). The dinoflagellates were represented by a total of 67 species and varieties belong to 16 genera. The genera Tripos, Protoperidinium, Prorocentrum and Gonyaulax showed the highest number of species (28, 7, 5 and 5 species, respectively). In addition, 3 species within 3 genera of cyanobacteria, 2 species within 2 genera of coccolithophores and only one species from each of silicoflagellates and chlorophytes were recorded. The long-term study of phytoplankton community in the Red Sea revealed that the genus Tripos suffered from pronounced changes in its diversity between 47 Dowidar (1983), 51 species (Ismael 2015) and 28 species during the present study. Such difference could be related to methodology of collection, temporal strategy of sampling and the area concerned in each study. Protoperidinium (7 species), Chaetoceros and Rhizosolenia 
(5 species) came in the second order which were pronouncedly more diversified in the records of Ismael (2015) as follows; Protoperidinium (39 species); Chaetoceros (27 species) and Rhizosolenia (16).

Table 1: List of the phytoplankton species recorded in the present study with comparison to the recorded species in the previous studies.

\begin{tabular}{|c|c|c|c|}
\hline Species in the present study & $\begin{array}{c}\text { Nassar and Khairy }{ }^{\mathrm{a}} \\
(\mathbf{2 0 1 4})\end{array}$ & Ismael $^{\mathrm{b}}($ 2015) & $\begin{array}{c}\text { Devassy } \text { et al. } \\
(2017)\end{array}$ \\
\hline \multicolumn{4}{|l|}{ Diatoms } \\
\hline \multicolumn{4}{|l|}{ Centric diatoms } \\
\hline Actinocyclus octonarius ${ }^{\mathrm{a}, \mathrm{c}}$ & & + & \\
\hline Azpeitia nodulifera $^{\mathrm{c}}$ & + & + & \\
\hline Bacteriastrum delicatulum $^{\text {a }}$ & & + & + \\
\hline Cerataulina pelagic & + & + & + \\
\hline Chaetoceros anastomosans $^{\mathrm{c}}$ & + & + & \\
\hline Chaetoceros decipiens & + & + & + \\
\hline Chaetoceros lorenzianus $^{\mathrm{c}}$ & + & + & \\
\hline Chaetoceros peruvianus & + & + & + \\
\hline \multicolumn{4}{|l|}{ Chaetoceros simplex* } \\
\hline Cocconeis placentula ${ }^{\mathrm{c}}$ & + & + & \\
\hline Coscinodiscus centralis s, $^{\mathrm{a}, \mathrm{c}}$ & & + & \\
\hline \multicolumn{4}{|l|}{ Coscinodiscus concavus* } \\
\hline Coscinodiscus granii & + & + & + \\
\hline Coscinodiscus radiates & + & + & + \\
\hline Guinardia flaccid & + & + & + \\
\hline Guinardia striata $^{\mathrm{b}}$ & + & & + \\
\hline Hemiaulus hauckii & + & + & + \\
\hline 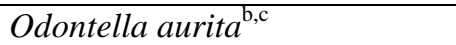 & + & & \\
\hline Paralia sulcata $^{\mathrm{b}, \mathrm{c}}$ & + & & \\
\hline Proboscia alata & + & + & + \\
\hline Pseudosolenia calcar-avis & + & + & + \\
\hline Rhizosolenia bergonii & + & + & + \\
\hline Rhizosolenia imbricate & + & + & + \\
\hline \multicolumn{4}{|l|}{ Triceratium favus* } \\
\hline \multicolumn{4}{|l|}{ Pennate diatoms } \\
\hline Amphora lineolata ${ }^{\mathrm{b}}$ & + & & + \\
\hline${\text { Asterionellopsis } \text { glacialis }^{\mathrm{b}}}$ & + & & + \\
\hline Bacillaria paxillifera $^{\mathrm{a}, \mathrm{b}}$ & & & + \\
\hline Cymbella ventricosa $^{\mathrm{b}, \mathrm{c}}$ & + & & \\
\hline Diploneis crabro ${ }^{\mathrm{a}}$ & & + & + \\
\hline \multicolumn{4}{|l|}{ Diploneis weissflogii* } \\
\hline Entomoneis paludosa $a^{\mathrm{b}, \mathrm{c}}$ & + & & \\
\hline \multicolumn{4}{|l|}{ Fogedia finmarchica* } \\
\hline \multicolumn{4}{|l|}{ Fragilariopsis cf. kerguelensis* } \\
\hline Grammatophora marina $^{\mathrm{b}, \mathrm{c}}$ & + & & \\
\hline Gyrosigma attenuatum $^{\mathrm{b}}$ & + & & + \\
\hline \multicolumn{4}{|l|}{ Gyrosigma balticum* } \\
\hline \multicolumn{4}{|l|}{ Halamphora coffeiformis* } \\
\hline \multicolumn{4}{|l|}{ Haslea balearica* ${ }^{*}$} \\
\hline Iconella hibernica $^{\mathrm{b}, \mathrm{c}}$ & + & & \\
\hline Licmophora abbreviata $^{\mathrm{b}, \mathrm{c}}$ & + & & \\
\hline Licmophora flabellata $^{\mathrm{b}}$ & + & & + \\
\hline 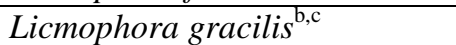 & + & & \\
\hline Lyrella clavata $^{\mathrm{a}, \mathrm{b}}$ & & & + \\
\hline Lyrella lyra $^{\mathrm{b}}$ & + & & + \\
\hline Mastogloia erythraea* & & & \\
\hline
\end{tabular}


Con: Table 1

\begin{tabular}{|c|c|c|c|}
\hline Species in the present study & $\begin{array}{c}\text { Nassar and Khairy }^{\mathrm{a}} \\
(\mathbf{2 0 1 4})\end{array}$ & Ismael $^{\mathrm{b}}(\mathbf{2 0 1 5})$ & $\begin{array}{c}\text { Devassy } e^{\text {et } a l .}{ }^{\mathrm{c}} \\
(2017)\end{array}$ \\
\hline Mastogloia sp. ${ }^{\mathrm{a}, \mathrm{c}}$ & & + & \\
\hline Navicula cancellata ${ }^{\mathrm{b}, \mathrm{c}}$ & + & & \\
\hline Nitzschia longissima & + & + & + \\
\hline Nitzschia sigma ${ }^{\mathrm{c}}$ & + & + & \\
\hline \multicolumn{4}{|l|}{ Petroneis cf. marina* } \\
\hline \multicolumn{4}{|l|}{ Petroneis monilifera* } \\
\hline \multicolumn{4}{|l|}{ Pinnularia cruciformis* } \\
\hline \multicolumn{4}{|l|}{ Plagiodiscus nervatus* } \\
\hline Plagiotropis lepidoptera ${ }^{\mathrm{b}}$ & + & & + \\
\hline \multicolumn{4}{|l|}{ Pleurosigma cf. diverse-striatum* } \\
\hline Pleurosigma formosum ${ }^{\mathrm{a}, \mathrm{c}}$ & & + & \\
\hline Pseudo-nitzschia pungens ${ }^{\mathrm{c}}$ & + & + & \\
\hline Striatella unipunctata ${ }^{\mathrm{b}, \mathrm{c}}$ & + & & \\
\hline \multicolumn{4}{|l|}{ Surirella fastuosa* } \\
\hline Synedra ulna ${ }^{\mathrm{c}}$ & + & + & \\
\hline Thalassionema frauenfeldii ${ }^{\mathrm{c}}$ & + & + & \\
\hline Thalassionema nitzschioides & + & + & + \\
\hline \multicolumn{4}{|l|}{ Trachyneis aspera* } \\
\hline Tryblionella punctata ${ }^{\mathrm{a}, \mathrm{b}}$ & & & + \\
\hline \multicolumn{4}{|l|}{ Dinoflaellates } \\
\hline \multicolumn{4}{|l|}{ Archaeperidinium minutum* } \\
\hline Ceratocorys armata ${ }^{\mathrm{a}}$ & & + & + \\
\hline Ceratocorys gourretii $^{\mathrm{a}}$ & & + & + \\
\hline Ceratocorys horrida $^{\mathrm{a}}$ & & + & + \\
\hline \multicolumn{4}{|l|}{ Coolia cf. monotis* } \\
\hline \multicolumn{4}{|l|}{ Dinophysis acuta* } \\
\hline Dinophysis caudate & + & + & + \\
\hline Dinophysis miles $^{\mathrm{a}}$ & & + & + \\
\hline Excuvilla compressa ${ }^{\mathrm{b}, \mathrm{c}}$ & + & & \\
\hline Goniaulax digitalis $^{\mathrm{a}, \mathrm{b}}$ & & & + \\
\hline Goniaulax kofoidii $^{\mathrm{a}, \mathrm{b}}$ & & & + \\
\hline \multicolumn{4}{|l|}{ Goniaulax striatum* } \\
\hline Gonyaulax polygramma $^{\mathrm{a}}$ & & + & + \\
\hline Gonyaulax spinifera $^{\mathrm{a}}$ & & + & + \\
\hline \multicolumn{4}{|l|}{ Histioneis paulsenii* ${ }^{*}$} \\
\hline Lingulodinium polyedra ${ }^{\mathrm{a}, \mathrm{b}}$ & & & + \\
\hline Ornithocercus quadratus ${ }^{\mathrm{a}, \mathrm{c}}$ & & + & \\
\hline \multicolumn{4}{|l|}{ Oxytoxum sceptrum* ${ }^{*}$} \\
\hline Oxytoxum tesselatum ${ }^{\mathrm{a}, \mathrm{c}}$ & & + & \\
\hline \multicolumn{4}{|l|}{ Paleophalacroma unicinctum* } \\
\hline Phalacroma rapa ${ }^{\mathrm{c}}$ & + & + & \\
\hline Phalacroma rotundatum ${ }^{\mathrm{a}, \mathrm{b}}$ & & & + \\
\hline Podolampas palmipes $^{\mathrm{a}}$ & & + & + \\
\hline Podolampas spinifera $^{\mathrm{a}, \mathrm{b}}$ & & & + \\
\hline Prorocentrum compressum $^{\mathrm{a}, \mathrm{c}}$ & & + & \\
\hline Prorocentrum gracile & + & + & + \\
\hline Prorocentrum lima ${ }^{\mathrm{a}, \mathrm{b}}$ & & & + \\
\hline Prorocentrum micans & + & + & + \\
\hline \multicolumn{4}{|l|}{ Prorocentrum minimum $*$} \\
\hline Protoceratium cf. reticulatum $^{\mathrm{a}}$ & & + & + \\
\hline Protoceratium spinulosum ${ }^{\mathrm{a}, \mathrm{c}}$ & & + & \\
\hline Protoperidinium cerasus ${ }^{\mathrm{c}}$ & + & + & \\
\hline Protoperidinium depressum & + & + & + \\
\hline Protoperidinium divergens & + & + & + \\
\hline
\end{tabular}


Con: Table 1

\begin{tabular}{|c|c|c|c|}
\hline Species in the present study & $\begin{array}{c}\text { Nassar and Khairy }^{\mathrm{a}} \\
(\mathbf{2 0 1 4})\end{array}$ & Ismael $^{b}(2015)$ & $\begin{array}{c}\text { Devassy et al. } \\
(2017)\end{array}$ \\
\hline Protoperidinium elegance $^{\mathrm{a}}$ & & + & + \\
\hline Protoperidinium pellucidum $^{\mathrm{a}, \mathrm{c}}$ & & + & \\
\hline Protoperidinium solidicorne $e^{\mathrm{a}, \mathrm{c}}$ & & + & \\
\hline Protoperidinium steinii & + & + & + \\
\hline Pyrodinium bahamense $\mathrm{a}^{\mathrm{a}, \mathrm{c}}$ & & + & \\
\hline \multicolumn{4}{|l|}{ Tripos angustocornis* } \\
\hline Triposbrevis & + & + & + \\
\hline \multicolumn{4}{|l|}{ Tripos brevis var. curvulus ${ }^{*}$} \\
\hline Tripos candelabrus & + & + & + \\
\hline 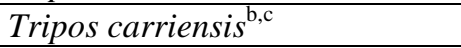 & & & + \\
\hline Tripos contortus $^{\mathrm{a}}$ & & + & + \\
\hline Tripos declinatus $^{\mathrm{a}}$ & & + & + \\
\hline \multicolumn{4}{|l|}{ Tripos deflexus* } \\
\hline \multicolumn{4}{|l|}{ Tripos eugrammus* } \\
\hline Tripos extensus ${ }^{\mathrm{c}}$ & + & + & \\
\hline Tripos furca & + & + & + \\
\hline Tripos fusus & + & + & + \\
\hline \multicolumn{4}{|l|}{ Tripos hircus* } \\
\hline Tripos horridus $^{\mathrm{a}}$ & & + & + \\
\hline Tripos horridus var. buceros ${ }^{\mathrm{a}, \mathrm{c}}$ & & + & \\
\hline Tripos incisus ${ }^{\mathrm{a}}$ & & + & + \\
\hline Tripos inflatus $^{\mathrm{a}}$ & & + & + \\
\hline Tripos kofoidii & + & + & + \\
\hline Tripos macroceros & + & + & + \\
\hline Tripos massiliensis & + & + & + \\
\hline Tripos muelleri & + & + & + \\
\hline \multicolumn{4}{|l|}{ Tripos muelleri var. atlanticus* } \\
\hline Tripos pentagonus $^{\mathrm{a}}$ & & + & + \\
\hline \multicolumn{4}{|l|}{ Tripos saltans $*$} \\
\hline Tripos setaceus ${ }^{\mathrm{b}, \mathrm{c}}$ & + & & \\
\hline Tripos teres ${ }^{\mathrm{a}}$ & & + & + \\
\hline Tripos trichoceros & + & + & + \\
\hline Tripos vultur & & & + \\
\hline \multicolumn{4}{|l|}{ Cyanobacteria } \\
\hline Chroococcus turgidus ${ }^{\mathrm{b}, \mathrm{c}}$ & + & & \\
\hline Oscillatoria tenuis ${ }^{\mathrm{b}, \mathrm{c}}$ & + & & \\
\hline Trichodesmium erythraeum $^{\mathrm{c}}$ & + & + & \\
\hline \multicolumn{4}{|l|}{ Chlorophytes } \\
\hline \multicolumn{4}{|l|}{ Pterosperma undulatum* } \\
\hline \multicolumn{4}{|l|}{ Silicoflagellates } \\
\hline Dictyocha fibula $^{c}$ & + & + & \\
\hline \multicolumn{4}{|l|}{ Coccolithophores } \\
\hline \multicolumn{4}{|l|}{ Emiliania huxleyi* } \\
\hline Coronosphaera mediterranea* & & & \\
\hline
\end{tabular}

*new records

a, b, c Species did not list by Nasser and Khairy (2014), Ismael (2015)and Devassy et al. (2017), respectively

Although, the majority of studies indicated higher diversity of phytoplankton in the eastern Red Sea coast than the western coast (Shaikh et al. 1986; Dowidar et al. 1978), the present study revealed clear similarity in species composition of Hurghada with that observed in the Saudi Arabia coast by Devassy et al. (2017). Halim (1969), Madkour et al. (2010) and Ismael (2015) stated that the number of dinoflagellate 
species was higher than that of diatoms in the Red Sea proper. These observations support the present findings, but with little difference between the two groups (64 diatoms and 67 dinoflagellates). Increasing number of diatom species with that of dinoflagellates is a common characteristic in the western coast of the Red Sea (Ibrahim 1988; El-Shrif and Abo El-Ezz 2000; Deyab et al. 2004; Abel Rahman and Nassar 2005; Nassar et al. 2014). This contradicts with observations of the present study as well as with those of Halim (1969) and Ismael (2015). This could be related to dinoflagellates disability to tolerate pollution (Smayda and Shimizu 1993) which also can be source to increase silicate in water, hence increase diversity of diatoms in their sampling site (Deyab et al. 2004).

\section{ACKNOWLEDGMENT}

Because this study is a part of the project ID 5618 entitled "Utilization of ichthyplankton (fish eggs and larvae) for the management of the Red Sea fisheries", so, special thanks to the Science and Technology Development Funding (STDF).

\section{REFERENCES}

Abel Rahman, N. S. and Nassar, M. Z. (2005). Preliminary studies on plankton communities associated with the mangrove forest habitats at Halayib-Shalatin sector, Red Sea, Egypt. Pakistan Journal of Marine Sciences, 14(2): 133-144.

Al-Kandari, M.; Al-Yamani, F. and Al-Rifaie, K. (2009). Marine Phytoplankton Atlas of Kuwait's Waters. Kuwait Institute for Scientific Research.

Baars, M. A.; Schalk, P. H. and Veldhuis, M. J. W. (1998). Seasonal fluctuations inplankton biomass and productivity in the ecosystems of the Somali Current, Gulf of Aden, and Southern Red Sea. In: Sherman et al. (eds) Large marine ecosystems of the Indian Ocean: assessment, sustainability, and management. Blackwell Science, Oxford, 143-174.

Cleve, P. T. (1900). Plankton from the Red Sea. Öfvers K Vetensk Akad Förh, 57(9): $1025-1038$.

Cleve, P. T. (1903). Report on plankton collected by Mr. Thorild Wulff during a voyage to and from Bombay. Arkivför Zoology, Stockholm, 1: 329-381.

Cupp, E. E. (1943). Marine plankton diatoms of the west coast of North America. University of California Press, Berkely and Los Angeles, California, pp 238.

Devassy, R. P.; Al-Aidaroos, A. M.; El-Sherbiny, M. M. and Abdul Mohsin AlSofyani, A. M. (2017). Spatial variation in the phytoplankton standing stock and diversity in relation to the prevailing environmental conditions along the Saudi Arabian coast of the northern Red Sea. Marine biodiversity, 47(4): 9951008.

Devassy, R. P.; Al-Aidaroos, A. M.; El-Sherbiny, M. M. and Kürten, B. (2016). Biodiversity of marine net-phytoplankton in the oligotrophic Red sea, with special reference to diatoms and dinoflagellates. International Conference on Marine Environment of the Red Sea (ICMERS), Faculty of marine Sciences, King Abdul Aziz University; Nov 14-16; Saudi Arabia.

Deyab, M. A.; Khedr, A. A. and El-Naggar, M. A. (2004). Phytoplankton distribution in relation to environmental factor along the Suez Canal and the Red Sea coast of Egypt. Algological studies, 112: 123-140.

Dodge, J. D. (1982). Marine Dinoflagellates of the British Isles. Her Majesty's Stationary Office, London. 
Dodge, J. D. (1985). Atlas of Dinoflagellates. Botany Department. Royal Holloway. Bedford Colleges (University of London), Egham.

Dowidar, N. M. (1983). The genus Ceratium from the Red Sea. Journal of Faculty of Marine Science. King Abdel-Aziz University, Jeddah, 3: 5-37.

El-Sherif, Z. M. and Aboul-Ezz, S. (2000). Checklist of plankton of the northern Red Sea. Pakistan Journal of Marine Sciences, 9 (1-2): 61-78.

Halim, Y. (1969). Plankton of the Red Sea.Oceanography and Marine Biology - An Annual Review, 7:231-275.

Hendey, N. I. (1946). An Introductory Account of the Smaller Algae of Biritish Coastal Waters. Part V: Bacillariopycea (Diatoms). Her Majesty's Stationery Office, London.

Ibrahim, E. A. (1988). Observations on the distribution of phytoplankton in Foul Bay, Red Sea. Bulletin of Institute of Oceanography and Fisheries, A. R. E., 14(1): 91-103.

Ismael, A. A. (2015). Phytoplankton of the Red Sea. In: NMA R, ICF S (eds) The Red Sea: the formation, morphology, oceanography and environment of a Young Ocean basin. Springer Earth System Sciences, Berlin, pp 1-28.

Karsten, G. (1907). Das indishe Phytoplankton. Wissen schaftliche Ergebnisse Valdivia, 2: 221-548.

Khalil, A. N. and Ibrahim, A. M. (1988). Seasonal study of the surface phytoplankton of the Red Sea North of Jeddah. Arabian Gulf Journal Scientific Research Agriculture and Biological Sciences, B6 (2): 189-204.

Kürten, B.; Khomayis, H. S.; Devassy, R.; Audritz, S.; Sommer, U.; Struck, U.; ElSherbiny, M. M. and Al-Aidaroos, A. M. (2015). Ecohydrographic constraints on biodiversity and distribution of phytoplankton and zooplankton in coral reefs of the Red Sea, Saudi Arabia. Marine Ecology, 36(4):1195-1214.

Madkour, F. F. (2000). Ecological studies on the phytoplankton of the Suez Canal. Ph. D. thesis, Facult of Science, Suez Canal Univ., Egypt.

Madkour, F. A.; Dorgham, M. M.; Hanafi, M. H. and Holligan, P. M. (2007). Comprehensive hydro-biological observations on the Suez Canal. International Journal of Oceans and Oceanography, 2(1): 125-137.

Madkour, F. F.; El-Sherbiny, M. M. and Aamer, M. A. (2010). Phytoplankton population along certain Egyptian coastal regions of the Red Sea. Egyptian Journal of Aquatic Biology and Fisheries, 14 (2): 95-109.

Matzenauer, L. (1933). Die Dinoflagellaten des Indischen Ozeans. Bot. Arch., 35:437-509.

Nassar, M. Z. and Khairy, H. M. (2014). Checklist of phytoplankton species in the Egyptian waters of the Red Sea and some surrounding habitats (1990-2010). Annual Research and Review in Biology, 4 (23): 3566-3585.

Nassar, M. Z.; Mohamed, H. R.; Khiray, H. M. and Rashedy, S. H. (2014). Seasonal fluctuations of phytoplankton community and physico-chemical parameters of the north western part of the Red Sea, Egypt. The Egyptian Journal of Aquatic Research, 40(4): 395-403.

Ostenfeld, C. H. and Schmidt, J. (1901). Plankton fradet Röde Hav Adenbugten. Videnskabelige Meddelelser Dansk Naturhistorisk Forening Kjobenhaven, 141182.

Schröder, B. (1906). Beitragezur Kenntnis der Phytoplanktons warmer Meeres Vierteljahrsschrift der Naturforschenden Gesellschaft in Zürich, 51: 319-377. 
Shaikh, E. A.; Roff, J. C. and Dowidar, N. M. (1986). Phytoplankton ecology and production in the Red Sea off Jiddah, Saudi Arabia. Marine Biology, 92:405416.

Smayda, T. J. and Shimizu, Y. (1993). Toxic phytoplankton blooms in the Sea. Elsevier, London.

Stewart, K. D. and Mattox, K. R. (1975). Comparative cytology evolution and classification of green algae with some consideration of the other organisms with chlorophylls a and b. Botanical Review, 41: 104-135.

Taylor, F. J. R. (1976). Dinoflagellates from the International Indian Ocean Expedition. Vol. 132, pp. 1-234. Bib. Bontica.

Tomas, C. R. (1997). Identifying marine phytoplankton. Academic Press: San Diego, $858 \mathrm{pp}$.

Touliabah, H. E.; Abu El-Kheir, W. S.; Kuchari, M. G. and Abdulwass, N. I. H. (2010). Phytoplankton composition at Jeddah coast-Red Sea, Saudi Arabia in relation to some ecological factors. J King Abdulaziz Univ Sci, 22(1):115-131.

Young, J. R.; Geisen, M.; Cros, L.; Kleijne, A.; Sprengel, C.; Probert, I. and Ostergaard, J. B. (2003). A guide to extant calcareous nannoplankton taxonomy. Journal of Nannoplankton Research. 1: 1-125.

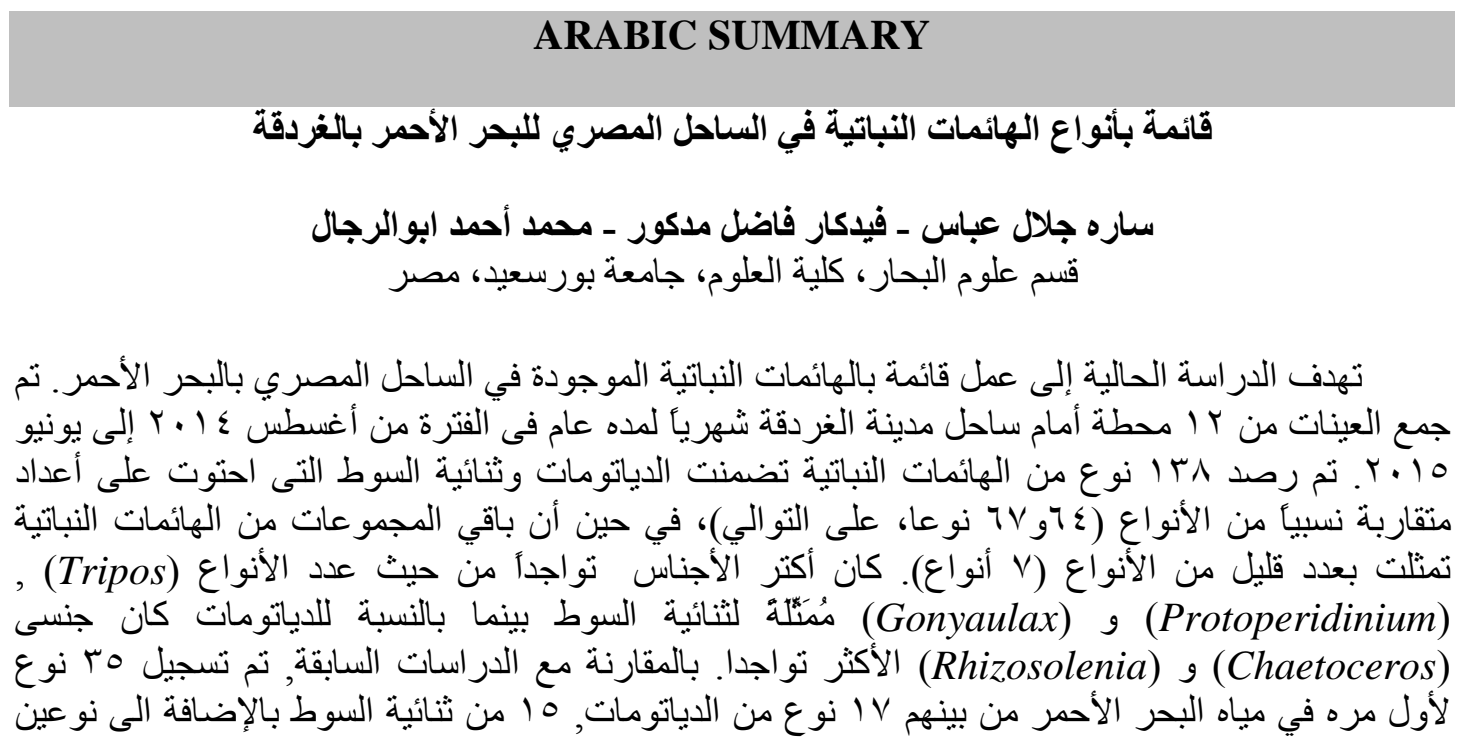

من مجمو عة (Coccolithophores). 